\title{
The dardarin G2019S mutation is a common cause of Parkinson's disease but not other neurodegenerative diseases
}

\author{
Dena Hernandez ${ }^{\mathrm{a}}$, Coro Paisan Ruiz ${ }^{\mathrm{a}}$, Anthony Crawley ${ }^{\mathrm{a}}$, Roneil Malkani ${ }^{\mathrm{a}}$, \\ John Werner ${ }^{\mathrm{a}}$, Katrina Gwinn-Hardy ${ }^{\mathrm{a}}$, Dennis Dickson ${ }^{\mathrm{b}}$, Fabienne Wavrant DeVrieze ${ }^{\mathrm{a}}$, \\ John Hardy ${ }^{\mathrm{a}, *}$, Andrew Singleton ${ }^{\mathrm{a}}$ \\ ${ }^{a}$ Laboratory of Neurogenetics, National Institutes on Aging and of Neurological Diseases and Stroke, Porter Neuroscience Building, \\ Building 10, Room 6C103, 35, Convent Drive, Bethesda, MD 20892, USA \\ ${ }^{\mathrm{b}}$ Birdsall Building, Mayo Clinic Jacksonville, 4500 San Pablo Road, Jacksonville, FL 32224, USA
}

Received 28 June 2005; received in revised form 19 July 2005; accepted 20 July 2005

\begin{abstract}
Mutations in the leucine-rich kinase 2 gene (LRRK2) encoding dardarin, on chromosome 12, are a common cause of familial and sporadic Parkinson's disease. The most common mutation, a heterozygous 6055G > A transition (G2019S) accounts for approximately 3-10\% of familial Parkinson's disease and 1-8\% sporadic Parkinson's disease in several European-derived populations. Some families with disease caused by $L R R K 2$ mutations have been reported to include patients with highly variable clinical and pathological features. We screened for the most common LRRK2 mutation in a series of patients with Parkinson's Disease, Alzheimer's disease, Progressive Supranuclear Palsy, Multiple System Atrophy and frontotemporal dementia, as well as in neurologically normal controls. The mutation was found only in Parkinson's disease patients or their relatives and not in those with other neurodegenerative disease.
\end{abstract}

(c) 2005 Elsevier Ireland Ltd. All rights reserved.

Keywords: Parkinson's disease; Parkinsonism; Dementia; LRRK2; Dardarin genetics

Parkinson's disease is a common neurodegenerative disorder, affecting $3 \%$ of those $>75$ years of age [3]. It is associated with resting tremor, postural rigidity and bradykinesia. The neuropathologic hallmarks of Parkinson's disease are loss of dopaminergic neurons and deposition of cytoplasmic aggregates termed Lewy bodies, which contain $\alpha$-synuclein and ubiquitin, especially in the substantia nigra.

Genetic analysis has implicated several genes in parkinsonian syndromes [7]. Most recently, mutations in the LRRK2 gene were reported [15]. These mutations occurred in several families whose clinical features were usually of Parkinson's disease $[8,16,17,19]$. However, some families show neuropathological heterogeneity with some affected individuals exhibiting Lewy bodies, in association with neuronal loss and gliosis in the substantia nigra [6] and others having either tau pathology and resembling progressive supranuclear palsy and

\footnotetext{
* Corresponding author. Tel.: +1 301451 3829; fax: +1 3014800335

E-mail address: hardyj@mail.nih.gov (J. Hardy).
}

Table 1

Number of cases screened for the G2019S dardarin mutation

\begin{tabular}{lc}
\hline Diagnosis & G2019S screened \\
\hline Parkinson's disease & 719 \\
Late onset Alzheimer's disease & 1444 \\
Progressive Supranuclear Palsy & 186 \\
Essential tremor & 18 \\
Restless leg syndrome & 94 \\
Frontal temporal dementia and CBGD/tauopathy & 40 \\
Dystonia & 17 \\
Controls & 2680
\end{tabular}

CBGD: cortical-basal ganglionic degeneration.

still others lacking distinctive histopathology; these pathologies occurred in the context of variable clinical phenotypes $[5,19]$. This variety of clinical and pathological features associated with patients possessing LRRK2 mutations suggests that they can lead to the central pathogenic event of nigral degeneration, and produce parkinsonian phenotypes, along with variable pathological features [19]. Furthermore, the 
Table 2

Characteristics of cases with mutations

\begin{tabular}{llllll}
\hline Diagnosis & Age & Age at onset & Gender & Family history & Ancestry \\
\hline PD & 72 & 58 & $\mathrm{M}$ & None & Northern European \\
Dystonia & 60 & 57 & $\mathrm{M}$ & Positive for PD & Eastern European \\
PD & Not known & Not known & $\mathrm{M}$ & Positive & Northern European \\
PD & 75 & 70 & $\mathrm{~F}$ & None & Northern European \\
PD & 60 & 58 & $\mathrm{~F}$ & None & Northern European \\
Blood relative of PD case & 50 & Currently well & $\mathrm{F}$ & Positive & Eastern European \\
Blood relative of PD case & 53 & Currently well & $\mathrm{F}$ & Positive & Eastern European \\
PD & 63 & 62 & $\mathrm{M}$ & None & South American \\
PD & 43 & Not known & $\mathrm{M}$ & None & Eastern European \\
\hline
\end{tabular}

M: male; F: female; PD: Parkinson's disease.

location of the $L R R K 2$ gene on chromosome 12 close to a linkage peak for late onset Alzheimer's disease has led to the suggestion that variability at $L R R K 2$ may predispose to Alzheimer's disease [13,19].

The predicted product of the $L R R K 2$ gene is the large protein, dardarin, which is expected to have 2527 amino acids encoded by 51 exons [19]. One mutation, c.6055G $>\mathrm{A}$ in exon 41 of $L R R K 2$, encodes a G2109S change in the predicted kinase site of dardarin [8]. This mutation is extremely common in populations of European origin and accounts for between 1 and $10 \%$ of Parkinson's disease depending on the geographic location. With this background, we determined to assess whether this mutation occurred in other neurodegenerative diseases. We, therefore, screened a large number of Caucasian Parkinson's disease cases, Alzheimer's disease cases and Progressive Supranuclear Palsy cases for this mutation (Table 1).

DNA was extracted using standard methodologies. Most genotyping was performed using TaqMan single-nucleotidepolymorphism assay (Assays-by-Design Service, Applied Biosystems, Foster City, CA, USA) and an ABI 7900, although some cases were screened directly by sequencing. All variants identified by TaqMan assay were confirmed by direct sequencing. Most of the samples we used are parts of series we have published previously $[10,13,18]$.

The dardarin mutation G2019S was identified primarily in Parkinson's disease cases ( 7 out of $719 ; 1 \%$ of PD cases tested: this does not include other families we have recently reported; refs. [2,8,10,14-17]) but additionally in a single case presenting with dystonia who had a family history of Parkinson's disease. While our samples series are not population based, these figures are completely concordant with our and others' work detailing the prevalence of the mutation in Parkinson's disease $[1,2,4,6,11,12,14]$. The mean age at onset noted in the patients studied here is $61 \pm 5.4$ S.D. years, comparable with the mean age at onset previously reported for $\mathrm{G} 2019 \mathrm{~S}$ carriers of $57.8 \pm 6.7[1,2,4,6,8,14,16]$. In this series, none of the cases had neuropathological confirmation, so we cannot be sure that individuals had Lewy bodies, although statistically, one would assume that the majority would have this pathology [9]. The mutation did not occur in large numbers of cases of late onset Alzheimer's disease, progressive supranuclear palsy or frontal dementia. While we cannot exclude that other, rare mutations occur in these other conditions, such a finding would suggest that the mutations would have to have subtly different pathogenic mechanisms; however, in our more limited full-gene sequencing efforts (unpublished), we have similarly not found mutations in any circumstance other than Parkinson's disease. Pleomorphic pathology and unusual clinical presentations clearly do occur in cases with dardarin mutations [19]; however, these results suggest that these are the exception not the rule and that most cases with dardarin mutations will develop typical Parkinson's disease (Table 2).

Finally, our continued failure to find this mutation in controls is notable; we have now failed to find the variant in $>5000$ normal chromosomes mostly from elderly individuals, assuming that a frequency of $1 \%$ (1/200 chromosomes) in Parkinson's disease cases suggests that having the mutation increases the risk of developing Parkinson's disease by $>25$ fold. Given this, the utility of following mutation carriers to determine early symptoms of the disease is clear.

\section{References}

[1] J.O. Aasly, M. Toft, I. Fernandez-Mata, J. Kachergus, M. Hulihan, L.R. White, M. Farrer, Clinical features of LRRK2-associated Parkinson's disease in central Norway, Ann. Neurol. 57 (5) (2005) 762765 .

[2] J.M. Bras, R.J. Guerreiro, M.H. Ribeiro, C. Januario, A. Morgadinho, C.R. Oliveira, L. Cunha, J. Hardy, A. Singleton, Mutations in LRRK2 are a common cause of Parkinson's disease in a Portuguese cohort, Mov. Disord., in press.

[3] M.C. de Rijk, W.A. Rocca, D.W. Anderson, M.O. Melcon, M.M. Breteler, D.M. Maraganore, A population perspective on diagnostic criteria for Parkinson's disease, Neurology 48 (5) (1997) 1277-1281.

[4] A. Di Fonzo, C.F. Rohe, J. Ferreira, H.F. Chien, L. Vacca, F. Stocchi, L. Guedes, E. Fabrizio, M. Manfredi, N. Vanacore, S. Goldwurm, G. Breedveld, C. Sampaio, G. Meco, E. Barbosa, B.A. Oostra, V. Bonifati, Italian Parkinson Genetics Network, A frequent LRRK2 gene mutation associated with autosomal dominant Parkinson's disease, Lancet 365 (9457) (2005) 412-415.

[5] M. Funayama, K. Hasegawa, E. Ohta, N. Kawashima, M. Komiyama, H. Kowa, S. Tsuji, F. Obata, An LRRK2 mutation as a cause for the parkinsonism in the original PARK8 family, Ann. Neurol. 57 (6) (2005) 918-921.

[6] W.P. Gilks, P.M. Abou-Sleiman, S. Gandhi, S. Jain, A. Singleton, A.J. Lees, K. Shaw, K.P. Bhatia, V. Bonifati, N.P. Quinn, J. Lynch, D.G. Healy, J.L. Holton, T. Revesz, N.W. Wood, A common LRRK2 
mutation in idiopathic Parkinson's disease, Lancet 365 (9457) (2005) 415-416.

[7] K. Gwinn-Hardy, Genetics of parkinsonism, Mov. Disord. 17 (4) (2002) 645-656.

[8] D.G. Hernandez, C. Paisan-Ruiz, A. McInerney-Leo, S. Jain, A. Meyer-Lindenberg, E.W. Evans, K.F. Berman, J. Johnson, G. Auburger, A.A. Schaffer, G.J. Lopez, R.L. Nussbaum, A.B. Singleton, Clinical and positron emission tomography of Parkinson's disease caused by LRRK2, Ann. Neurol. 57 (3) (2005) 453-456.

[9] A.J. Hughes, S.E. Daniel, A.J. Lees, Improved accuracy of clinical diagnosis of Lewy body Parkinson's disease, Neurology 57 (8) (2001) 1497-1499.

[10] J. Johnson, S.M. Hague, M. Hanson, A. Gibson, K.E. Wilson, E.W. Evans, A.A. Singleton, A. McInerney-Leo, R.L. Nussbaum, D.G. Hernandez, M. Gallardo, I.G. McKeith, D.J. Burn, M. Ryu, O. Hellstrom, B. Ravina, J. Eerola, R.H. Perry, E. Jaros, P. Tienari, R. Weiser, K. Gwinn-Hardy, C.M. Morris, J. Hardy, A.B. Singleton, SNCA multiplication is not a common cause of Parkinson disease or dementia with Lewy bodies, Neurology 63 (3) (2004) 554-556.

[11] J. Kachergus, I.F. Mata, M. Hulihan, J.P. Taylor, S. Lincoln, J. Aasly, J.M. Gibson, O.A. Ross, T. Lynch, J. Wiley, H. Payami, J. Nutt, D.M. Maraganore, K. Czyzewski, M. Styczynska, Z.K. Wszolek, M.J. Farrer, M. Toft, Identification of a novel LRRK2 mutation linked to autosomal dominant parkinsonism: evidence of a common founder across European populations, Am. J. Hum. Genet. 76 (4) (2005) 672-680 (Epub 2005 Feb 22).

[12] I.F. Mata, J.P. Taylor, J. Kachergus, M. Hulihan, C. Huerta, C. Lahoz, M. Blazquez, L.M. Guisasola, C. Salvador, R. Ribacoba, C. Martinez, M. Farrer, V. Alvarez, LRRK2 R1441G in Spanish patients with Parkinson's disease, Neurosci. Lett. 382 (3) (2005) 309-311 (Epub 2005 Apr 13).

[13] A. Myers, F. Wavrant De-Vrieze, P. Holmans, M. Hamshere, R. Crook, D. Compton, H. Marshall, D. Meyer, S. Shears, J. Booth, D. Ramic, H. Knowles, J.C. Morris, N. Williams, N. Norton, R. Abraham, P. Kehoe, H. Williams, V. Rudrasingham, F. Rice, P. Giles,
N. Tunstall, L. Jones, S. Lovestone, J. Williams, M.J. Owen, J. Hardy, A. Goate, Full genome screen for Alzheimer disease: Stage II analysis, Am. J. Med. Genet. 114 (2002) 235-244.

[14] W.C. Nichols, N. Pankratz, D. Hernandez, C. Paisan-Ruiz, S. Jain, C.A. Halter, V.E. Michaels, T. Reed, A. Rudolph, C.W. Shults, A. Singleton, T. Foroud, Parkinson Study Group-PROGENI investigators, Genetic screening for a single common LRRK2 mutation in familial Parkinson's disease, Lancet 365 (9457) (2005) 410-412.

[15] C. Paisan-Ruiz, S. Jain, E.W. Evans, W.P. Gilks, J. Simon, M. van der Brug, A.L. de Munain, S. Aparicio, A.M. Gil, N. Khan, J. Johnson, J.R. Martinez, D. Nicholl, I.M. Carrera, A.S. Pena, R. de Silva, A. Lees, J.F. Marti-Masso, J. Perez-Tur, N.W. Wood, A.B. Singleton, Cloning of the gene containing mutations that cause PARK8-linked Parkinson's disease, Neuron 44 (4) (2004) 595-600.

[16] C. Paisan-Ruiz, A.E. Lang, T. Kawarai, C. Sato, S. Salehi-Rad, G.K. Fisman, T. Al-Khairallah, P. St George-Hyslop, A. Singleton, E. Rogaeva, LRRK2 gene in Parkinson disease, Neurology (2005 Jun 15; Epub ahead of print).

[17] C. Paisan-Ruiz, A. Saenz, A.L. de Munain, I. Marti, A. Martinez Gil, J.F. Marti-Masso, J. Perez-Tur, Familial Parkinson's disease: clinical and genetic analysis of four Basque families, Ann. Neurol. 57 (3) (2005) 365-372.

[18] A.M. Pittman, A.J. Myers, P. Abou-Sleiman, H.C. Fung, M. Kaleem, L. Marlowe, J. Duckworth, D. Leung, D. Williams, L. Kilford, N. Thomas, C.M. Morris, D.W. Dickson, N.W. Wood, J. Hardy, A.J. Lees, R. de Silva, Linkage disequilibrium fine-mapping and haplotype association analysis of the tau gene in progressive supranuclear palsy and corticobasal degeneration, J. Med. Genet. (2005 Mar 25; Epub ahead of print).

[19] A. Zimprich, S. Biskup, P. Leitner, P. Lichtner, M. Farrer, S. Lincoln, J. Kachergus, M. Hulihan, R.J. Uitti, D.B. Calne, A.J. Stoessl, R.F. Pfeiffer, N. Patenge, I.C. Carbajal, P. Vieregge, F. Asmus, B. MullerMyhsok, D.W. Dickson, T. Meitinger, T.M. Strom, Z.K. Wszolek, T. Gasser, Mutations in LRRK2 cause autosomal-dominant parkinsonism with pleomorphic pathology, Neuron 44 (4) (2004) 601-607. 